\title{
Penerapan Sanksi Pelanggaran Administratif Pemilu bagi Penyelenggara Pemilu
}

\author{
Asbudi Dwi Saputra \\ Fakultas Hukum, Universitas Andi Djemma Palopo \\ Email Correspondensi: asbudidwi08@gmail.com \\ No. Handphone Correspondensi : (+62)85242743013
}

\section{Artikel info

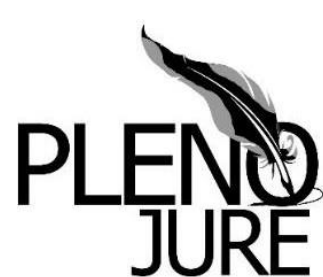 \\ Jurnal Ilmu Hukum \\ LL-DIKTI Wilayah IX \\ Sulawesi}

Artikel history:

Received; 30-09-2020

Revised:23-10-2020

Accepted;24-10-2020

\begin{abstract}
Abstrak. Penelitian ini bertujuan untuk mengetahui efektivitas penerapan sanksi pelanggaran administrasi pemilu bagi penyelenggara pemilu, karena penting diketahui tingkat penegakan hukumnya dimana hal tersebut dapat mempengaruhi jumlah suara perolehan pemilu. Artikel ini dibangun dengan tipe penelitian hukuym secara kualitatif dan menggunakan pendekatan penelitian hukum secara empiris. Hasil penelitian menunjukkan bahwa memahami penyelenggaraan pemilu butuh energi besar untuk benarbenar memahami agar dalam penyelenggaraannya tidak terjadi kesalahan. Anggaapan bahwa pemilu merupakan pesta rakyat biasa menyebabkan masyarakat melupakan bahwa konsekuensi dari kesalahan akan berdampak panjang hingga 5 tahun kedepan secara kongkrit. Hal ini juga mempengaruhi bahwa sanksi pelanggaran pemilu yang dianggap sebagai motivator untuk masyarakat dalam menaati hukum tidak berjalan sebagaimana diharapkan. Pada akhirnya artikel ini memperlihatkan penerapan sanksi Pelanggaran administrasi pemilu bagi penyelenggara pemilu tidak efektif karena sanksi yang dapat dijatuhkan bagi penyelanggara pemilu yang terbukti melakukan pelanggaran administratif pemilu hanya berupa teguran tertulis, tidak menimbulkan efek jera dan sanksi tersebut tidak berfungsi sebagai pencegahan agar penyelengara pemilu bekerja sesuai norma dan aturan yang berlaku.
\end{abstract}

\begin{abstract}
This study aims to determine the effectiveness of the application of sanctions for election administration violations for election organizers because it is important to know the level of law enforcement where it can affect the number of votes obtained in the election. This article was built with a qualitative legal research type and uses an empirical legal research approach. The research results show that understanding election administration requires a lot of energy to really understand so that there are no mistakes in the implementation. The assumption that elections are a party of ordinary people causes people to forget that the consequences of mistakes will have a concrete impact for the next 5 years. This also affects the sanctions for election violations that are considered as a motivator for the community to obey the law do not work as expected. In the end, this article shows that the application of sanctions for Election administration violations for election administrators is
\end{abstract}


ineffective because the sanctions that can be imposed on election administrators who are proven to have committed an election administrative violation are only in the form of a written warning, do not cause a deterrent effect and these sanctions do not serve as a deterrent so that the election administrators work accordingly. prevailing norms and rules.

\section{Keywords:}

Penerapan; Sanksi

Administrasi;

Pemilu;

artikel dengan akses terbuka dibawah lisensi CC BY-SA 4.0

\section{PENDAHULUAN}

Pemilu di Indonesia pada hakikatnya merupakan sarana pemenuhan demokrasi dari suatu negara, yakni perwujudan dari asas kedaulatan rakyat sebagaimana rumusan Pasal 1 ayat (2) Undang Undang Dasar Negara Kesatuan Republik Indonesia Tahun 1945. Menurut ketentuan Pasal 1 butir 1 Undang Undang Republik Indonesia Nomor 7 Tahun 2017 tentang Pemilihan Umum adalah sarana kedaulatan rakyat untuk memilih anggota Dewan Perwakilan Rakyat, anggota Dewan Perwakilan Daerah, Presiden dan Wakil Presiden, dan untuk memilih anggota Dewan Perwakilan Rakyat Daerah, yang dilaksanakan secara langsung, umum, bebas, rahasia, jujur, dan adil dalam Negara Kesatuan. ${ }^{1}$

Penyelenggaraan Pemilu DPR, DPD, DPRD Propinsi, DPRD Kabupaten/Kota dan Pemilihan Presiden dan Wakil Presiden tahun 2019 tidak lepas dari berbagai permasalahan hukum baik yang dikualifikasikan sebagai pelanggaran administrasi Pemilu, pelanggaran kode etik Penyelenggara Pemilu, sengketa Pemilu, tindak pidana Pemilu, maupun perselisihan suara hasil Pemilu. Pelanggaran administrasi Pemilu dapat terjadi dalam setiap tahapan penyelenggaraan pemilu DPR, DPD, DPRD Propinsi dan DPRD Kabupaten/Kota. Secara eksplisit pelanggaran administrasi pemilu dirumuskan dalam pasal 460 ayat 1 dan 2 Undang - undang Nomor 7 Tahun 2017mengenai penyelesaian pelanggaran administrasi pemilu pengaturannya terdapat dalam pasal 461, pasal 462, pasal 463 dan pasal 464 Undang - undang Nomor 7 Tahun 2017.Permasalahan mengenai pelanggaran administrasi dan sengketa tata usaha negara Pemilu, telah terjadi berulang kali dari setiap Pemilu. Dalam pemilu sebelumnya, permasalahan yang terjadi hampir serupa, yaitu masalah verifikasi, daftar pemilih, kampanye, dan rekapitulasi. Penanganan permasalahan tersebut juga masih berkisar pada perbedaan pendapat antara pelaksana Pemilu (KPU) dan pengawas (Bawaslu), hubungan dengan penegak hukum lainnya, serta permasalahan keterbatasan waktu. ${ }^{2}$

Pada pemilu 2019 yang lalu salah satu contohnya di Kota Palopo, terdapat beberapa catatan penting dalam penyelenggaraan Pileg dan Pilpres tersebut diantaranya pelanggaran administrasi Pemilu yang terjadi mengiringi pelaksanaan Pileg dan Pilpres tersebut. Pelanggaran-pelanggaran tersebut

\footnotetext{
${ }^{1}$ Mulyadi, D. (2019), Analisis Penerapan Bentuk-Bentuk Tindak Pidana Pemilu, Jurnal Ilmiah Galuh Justisi ,Vol. 7 No. 1- Maret 2019, hlm 16

${ }^{2}$ Hantoro. M. N. (2014), Pelanggaran Administrasi Pemilu Dan Sengketa Tata Usaha Negara Pemilu Anggota Dpr, Dpd, Dan Dprd Tahun 2014, Violation Of Administration And Administrative Dispute At The Election of Members Of Dpr, Dpd, And Dprd In 2014, Jurnal Negara Hukum : membangun hukum untuk keadilan dan kesejahteraan, Vol. 5 No.2 Tahun 2016, hlm 108
} 
sangat bervariasi, dari masalah teknis pemilihan yang tidak sesuai peraturan, seperti tidak menempel Daftar Pemilih Tetap (DPT) di Tempat Pemungutan Suara (TPS), tidak membubuhi paraf pada kesalahan penulisan dalam formulir $\mathrm{C} 1$, salah menghitung jumlah surat suara sah dan tidak sah sampai pelanggaran administrasi yang berakibat fatal seperti kesalahan penulisan dalam formulir C1 sehingga mengubah jumlah perolehan suara peserta pemilu, memberikan salinan formulir C1 kepada saksi parpol untuk diisi sendiri, KPPS memberikan surat suara kepada pemilih yang tidak berhak serta terdapat pula Ketua KPPS memberikan surat suara yang tidak ditanda tangani oleh ketua KPPS sehingga mengakibatkan surat suara pemilih tersebut tidak sah. ${ }^{3}$

Mengenai sanksi administrasi pemilu diatur dalam pasal 461 ayat 6 Undang - undang 7 Tahun 2017 . Berdasarkan pasal 461 ayat 6 Undang undang 7 Tahun 2017 khusus untuk penyelenggara pemilu sanksi yang dapat diberikan hanya perbaikan perbaikan administrasi terhadap tata cara, prosedur, atau mekanisme sesuai dengan ketentuan peraturan penrndangundangan dan teguran tertulis. Sedangkan pelanggaran administrasi pada pemungutan dan penghitungan suara yang dilakukan oleh penyelenggra pemilu bervariasi ada yang ringan tanpa menimbulkan dampak, namun ada pula yang berakibat fatal sehingga berdampak hilangnya hak suara dari pemilih dan dapat berakibat pemungutan/penghitungan suara ulang. Menjadi pertanyaan efektifkah sanksi administrasi pemilu dalam pasal 461 ayat 6 Undang - undang 7 Tahun 2017 bagi penyelenggra pemilu.

\section{METODE}

Metode penelitian ini menggunakan tipe penelitian hukum kualitatif dengan pendekatan penelitian hukum secara empiris. Penelitian ini dilaksanakan di Kota Palopo Sulawesi Selatan. Penelitian ini melihat secara langsung fenomena hukum yang terjadi di masyarakat khususnya penyelenggaraan pemilu di Kota Palopo. Pengamatan, observasi dan wawancara sebagai bahan untuk artikel ini sehingga dapat membuat suatu kesimpulan dengan tujuan untuk memberikan solusi terhadap permasalahan yang diteliti.

\section{HASIL DAN PEMBAHASAN}

\section{Efektivitas Penerapan Sanksi Administrasi Bagi Penyelenggara Pemilu Pasal 461 ayat (6) Undang - undang 7 Tahun 2017.}

Pada tahapan pemungutan dan rekapitulasi hasil penghitungan suara dalam pemilihan umum (pemilu), potensi hilang atau tercurinya suara pemilih baik secara sengaja atau tidak sengaja sangat mungkin terjadi, salah satunya karena tindakan mal-administrasi yang dilakukan oleh penyelenggara. Kesalahan atau kurangnya pengetahuan tentang tata cara atau prosedur penghitungan dan rekapitulasi perolehan suara pada umumnya menjadi pemicu munculnya permasalah ini. Di sisi lain, terdapat pula kepentingan para kontestan untuk memenangkan pemilu dengan segala cara, termasuk di dalamnya 'bekerjasama' dengan penyelenggara untuk mengubah hasil penghitungan suara sesuai pesanan kontestan. ${ }^{4}$

\footnotetext{
${ }^{3}$ Wawancara dengan Ahmad Ali, sebagai Anggota Bawaslu Kota Palopo, 15 September 2020

${ }^{4}$ Riza, F., Mohammad \& Ruhermansyah, (2019) Perihal Penegakan Hukum Pemilu Jakarta : Bawaslu, hlm 107
} 
Perbuatan-perbuatan yang dimaksud termasuk kategori perbuatan yang dilarang dalam Undang-Undang Pemilu, yaitu melakukan perbuatan yang menyebabkan suara seorang pemilih menjadi tidak bernilai atau menyebabkan peserta pemilu tertentu mendapat tambahan suara atau perolehan suara peserta pemilu menjadi berkurang; pada saat pemungutan suara mengaku dirinya sebagai orang lain; memberikan suara lebih dari satu kali di satu atau lebih TPS; menggagalkan pemungutan suara; tidak memberikan kesempatan kepada seorang pekerja untuk memberikan suaranya pada pemungutan suara, kecuali dengan alasan bahwa pekerjaan tersebut tidak bisa ditinggalkan; merusak atau menghilangkan hasil pemungutan suara; tidak memberikan surat suara pengganti hanya satu kali kepada pemilih yang menerima surat suara yang rusak; Memberikan pilihan kepada pemilih lain; Tidak menetapkan pemungutan suara ulang di TPS; menyebabkan rusak atau hilangnya berita acara pemungutan dan perhitungan suara dan sertifikat penghitungan suara yang sudah disegel; mengubah berita acara hasil penghitungan suara dan/atau sertifikat hasil penghitungan suara; mengakibatkan hilang atau berubahnya berita acara hasil rekapitulasi penghitungan perolehan suara dan/atau sertifikat penghitungan suara; merusak, menggangu, atau mendistorsi sistem informasi penghitungan suara hasil Pemilu. ${ }^{5}$

Praktik penyelenggaraan Pemilu tidak akan terlepas dari fenomena pelanggaran dan dilakukan oleh peserta Pemilu, pasangan calon, tim kampanye, calon legislatif dan/atau anggota masyarakatatau pemilih, bahkan penyelenggara Pemilu. ${ }^{6}$ Banyaknya jenis masalah serta banyaknya pihak yang terlibat menunjukkan begitu kompleknya masalah hukum pemilu, atau setidaktidaknya masalah hukum pemilu didesain dengan demikian kompleks. Jangankan untuk melaksanakan, memahaminya pun butuh energi ekstra agar tidak salah paham yang berakibat fatal dalam pelaksanaannya. Pada gilirannnya, pelaksanaan penegakan hukum pidana pemilu pun menghadapi berbagai persoalan, baik karena konten aturannya yang tidak terlalu mendukung maupun karena faktor penegak dan budaya hukum. ${ }^{7}$

Peranan sanksi hukum telah dirasakan selama ini, yakni merupakan salah satu motivator bagi masyarakat untuk dapat mentaati aturan hukum. Di samping itu ia berfungsi sebagai faktor yang dapat mempengaruhi efektivitas hukum dalam melaksanakan fungsinya sebagai sarana kontrol social. Pengertian sanksi dapat pula berupa tindakan putusan yang diambil oleh negara terhadap seseorang aparatur di luar hukum pidana dan perdata, misalnya sanksi administratif dengan kata lain bahwa sanksi mempunyai pengaruh yang sangat besar bagi pelaksanaan tugas kepemiluan penyelenggara pemilu. Secara logika hal tersebut dapat diterima oleh karena dari segi psikologi manusia akan merasa terancam sanksi apabila melakukan pelanggaran hukum. Dalam hubungan ini ancaman sanksi bagi penyelenggara

\footnotetext{
${ }^{5}$ Basuki, S. A. (2010), Tindak Pidana Pemilu Legislatif Di Kabupaten Banyumas Dan Purbalingga (Studi Tentang Kebijakan Formulasi Dan Penerapan Undang-Undang No. 10 Tahun 2008 Tentang Pemilihan Umum), Jurnal Dinamika Hukum Vol. 10 No. 2 Mei 2010, hlm 131 - 132

${ }^{6}$ Sekarwidhi, N.(2015). Penyelesaian Pelanggaran Pemilu Tahun 2014 Dan Pemilu Kepala Daerah Dan Wakil Kepala Daerah Tahun 2015 Di Jawa Tengah, Completion Of 2014 Election Violation And Regional Election And Regional Head Of Region In 2015 In Central Java .Science Government Fisip Undip, Semarang, Journal of Politic and Government Studies, vol. 7, no. 3, pp. 211-220, Jul. 2018. hlm 3

${ }^{7}$ Fahmi, K. (2015), Sistem Penanganan Tindak Pidana Pemilu, System for The Crime of Election, Jurnal Konstitusi, Vol. 12, Nomor 2, Juni 2015, Hlm 265
} 
pemilu senantiasa menakuti-nakuti hingga dalam tindakannya senantiasa terkontrol dan berupaya untuk menghindari pelanggaran bukan hanya pelanggaran pidana pemilu tetapi juga pelanggaran administrasi pemilu. Hal tersebut akan terlaksana jika pelanggaran administrasi tersebut dibarengi sanksi yang tegas terhadap setiap pelanggran pemilu, dan sebaliknya jika sanksi yang mengancam adalah hanya teguran tertulis sebagaimana dalam pasal 461 ayat 6 Undang-Undang 7 Tahun 2017 tentunya sanksi tersebut tidak akan menimbulkan efek pencegahan maupun efek jera.

Pada pemilu 2019 di Kota Palopo, terdapat pelanggaran administrasi Pemilu yang terjadi mengiringi pelaksanaan Pileg dan Pilpres tersebut. Pelanggaran-pelanggaran tersebut sangat bervariasi, dari masalah teknis pemilihan yang tidak sesuai peraturan, seperti tidak menempel Daftar Pemilih Tetap (DPT) di Tempat Pemungutan Suara (TPS), tidak membubuhi paraf pada kesalahan penulisan dalam formulir $\mathrm{C} 1$, salah menghitung jumlah surat suara sah dan tidak sah sampai pelanggaran administrasi yang berakibat fatal seperti kesalahan penulisan dalam formulir C1 sehingga mengubah jumlah perolehan suara peserta pemilu, memberikan salinan formulir C1 kepada saksi parpol untuk diisi sendiri, KPPS memberikan surat suara kepada pemilih yang tidak berhak serta terdapat pula Ketua KPPS memberikan surat suara yang tidak ditanda tangani oleh ketua KPPS sehingga mengakibatkan surat suara pemilih tersebut tidak sah. ${ }^{8}$

Berdasarkan data pelanggaran administrasi pemilu di Kota Palopo, sanksi yang dijatuhkan yaitu hanya teguran tertulis sesuai sanksi yang ada pada pada pasal 461 ayat 6 Undang - undang 7 Tahun 2017 tentunya tidak sejalan dengan teori yang dikemukaan oleh Plato, Phytagoras dan Aristoteles, bahwa salah satu maksud ancaman sanksi adalah untuk menakut-nakuti manusia agar tidak melakukan pelanggaran hukum, dalam hal ini posisi ancaman sanksi adalah untuk pencegahan (preventive). ${ }^{9}$ Demikian pula pandangan dari Hans Kelsen bahwa sanksi diberikan oleh tatanan hukum dengan maksud menimbulkan perbuatan tertentu yang dianggap dikehendaki oleh pembuat undang-undang. Sanksi hukum memiliki karakter sebagai tindakan paksa. ${ }^{10}$ Dapat diperoleh kesimpulan bahwa sanksi yang diberikan untuk pencegahan dan tindakan paksa agar sejalan dengan aturan, tidak berlaku jika dikatikan dengan sanksi administrasi pemilu sebagai upaya agar penyelenggara bekerja sesuai norma/aturan yang berlaku. Jadi sanksi tersebut tidak mengandung muatan yang mengancam sehingga tidak berefek pada pencegahan.

Sanksi adalah cara-cara menerapkan suatu norma atau peraturan. Sanksi hukum adalah sanksi-sanksi yang digariskan atau diotorisasi oleh hukum. Setiap peraturan hukum mengandung atau menyiratkan sebuah statemen mengenai konsekuensi-konsekuensi hukum. ${ }^{11}$ Jika teguran tertulis yang diberikan sebenarnya itu bukanlah suatu konsekuensi hanya sebagai

\footnotetext{
${ }^{8}$ Wawancara dengan Ahmad Ali, sebagai Anggota Bawaslu Kota Palopo, 15 September 2020

${ }^{9}$ Nawi, S. (2013) Penelitian Hukum Normatif Versus Penelitian Hukum Empiris, Jakarta : Raja Grafindo Persada, hlm 171

${ }^{10}$ Kelsen, H, (2014) Teori Umum tentang Hukum dan Negara Terjemahan dari General Theory of Law and State Bandung : Nusa Media. hlm 72

${ }^{11}$ Friedman, M. L, (2013) Sistem Hukum Perspektif Ilmu Sosial terjemahan dari Buku Lawrance M. Friedman, The Legal System : Social Science Perspektif Bandung : Nusa Media, hlm 93
} 
pernyataan belaka bahwa telah terjadi pelanggran administrasi pemilu. Konsekuensi-konsekuensi ini adalah sanksi-sanksi janji-janji atau ancaman.

Betapa pun juga, teori apa pun mengenai sanksi harus bertolak dari penerimaan terhadap fakta bahwa ancaman hukuman cenderung untuk mencegah, persis seperti halnya imbalan cenderung untuk mendorong perilaku yang diimbali. ${ }^{12}$ Sebagai satu patokan umum, orang-orang selalu menginginkan hal yang menyenangkan dan memuaskan, dan mereka menghindari apa yang merugikan, hukuman, dan sakit.

Proposisi dasar demikian berpegang pada perilaku rasional atau untung-rugi. Ide pencegahan umum berarti, misalnya, bahwa ancaman hukum yang berat akan membuat takut penyelenggara mereka akan berpikir dua kali untuk melakukan pelanggran tersebut karena takut diberikan sanksi yang berat, pencegahan lainnya bahwa seorang pernah diberikan sanksi akan berpikir dua kali untuk melakukan pelanggran kembali. Jika tetap melakukan pelanggaran maka akan diberikan sanski akumulasi tentunya yang lebih berat karena pencegahan terutama terletak dalam bentuk ancaman. Asumsinya adalah bahwa orang-orang bereaksi terhadap hal tersebut. Jika kita memberikan ancaman hukum dan memberlakukannya, bisa jadi tetap ada beberapa pelanggaran yang tersisa, namun para calon pelanggar lainnya akan tercegah.

Pengaturan hukum tentang kepemiluan di Indonesia harus berdasarkan asas pemilihan umum, yakni bersih, jujur, umum, bebas, rahasia, dan adil. Terutama dalam hal penerapan sanksi pidana yang memberikan efek jera terhadap pelaku tindak pidana pemilu. Sehingga dapat memberikan pembelajaran terhadap masyarakat agar tidak melakukan pelanggaranpelanggaran dan kecurangan dalam pemilihan umum legislatif. ${ }^{13}$ Begitupun dalam sanksi administrative pemilu bagi penyelenggra pemilu sanksi harus lebih tegas sesuai dengan perbuatan dan dampak dari pelanggran administrative yang dilakukan agar penyelenggara bekerja sesuai norma/aturan yg berlaku

Suatu sanksi hukum diberikan melalui penerapan aktual atau, lebih khusus lagi, melalui ancaman atau janji. Sarana-sarana penyampaian sanksi dan tingkat penyampaiannya mewujudkan sebuah proses yang disebut sebagai penegakan hukum. Dan penegakan hukum ini akan tegak jika ditopang oleh ancaman sanksi yang tegas dan jelas. ${ }^{14}$

Salah satu bagian dari sistem penegakan hukum adalah penerapan sanksi hukum. Sanksi Hukum pada dasarnya merupakan implementasi atau bagian dari pertanggungjawaban hukum. Seseorang yang bertanggungjawab secara hukum atas perbuatan tertentu bahwa dia dapat dikenakan suatu sanksi dalam kasus perbuatannya bertentangan/berlawanan hukum. Dalam hukum administrasi, penggunaan sanksi administrasi merupakan penerapan kewenangan pemerintahan, di mana kewenangan ini berasal dari aturan hukum tertulis dan tidak tertulis. Pada umumnya, memberikan kewenangan

\footnotetext{
12Ibid, hlm 94

${ }^{13}$ Damanik. F. F, Kalo. S, Putera. E, Nasution, M (2018) , Perbuatan Mengaku Dirinya Sebagai Orang Lain Dalam Pemungutan Suara Pada Pemilihan Umum Legislatif (Studi Kasus: Putusan Nomor:01/Pid.S/2014/P.N.Mdn Dan Putusan Nomor:02/Pid.B/2014/P.N.Mdn), USU Law Journal, Vol.6. No.4 (Juli 2018), hlm 58

${ }^{14} \mathrm{Ibid}$, hlm 115
} 
untuk menegakkan norma-norma itu melalui penerapan sanksi bagi mereka yang melanggar norma-norma Hukum Administrasi. ${ }^{15}$

Penegakan Hukum Administrasi Negara diantaranya:

De Bestuursrechtelijke handhavings middelen omvatten (1) het toezich dat bestuursorganen kunnen uitoefenen op de naleving vande biji of krachtens de wet gestelde voorschriften en van de bij besluit individueel opgeledge verplichtingen, en (2) de toepassing van bestuursrechtelijk sanctie bevoegdheden. ${ }^{16}$

Artinya: (sarana penegakan Hukum Administrasi Negara berisi ; (1) pengawasan bahwa organ pemerintahan dapat melaksanakan ketaatan pada atau berdasarkan undang undang yang ditetapkan secara tertulis dan pengawasan terhadap keputusan yang meletakkan kewajiban kepada individu, dan (2), penerapan kewenangan sanksi pemerintahan.

Substansi dari Nicola ini mempertegas gagasan ten Berge sebagaimana dikutip Philipus. M. Hadjon,bahwa instrument penegakan Hukum Administrasi Negara meliputi pengawasan dan penegakan sanksi. Pengawasan merupakan langkah preventif untuk memaksakan kepatuhan, sedangkan penerapan sanksi merupakan langkah represif untuk memaksakan kepatuhan ${ }^{17}$.

Menurut Ridwan HR adalah sifat sanksi administrasi adalah reparatoircomdemnatoir yaitu pemulihan kembali pada keadaan semula dan memberikan hukuman sedangkan sanksi pidana bersifat comdemnatoir. ${ }^{18}$

Sanksi dalam Hukum Administrasi adalah ;

"De Publiekrechttelijke matchsmiddelen die de overhead kan aanwenden als reactive op niet-naleving van verplichtingen die voortvloein uit administratiefrechtelijke normen ${ }^{19}$

Artinya; yaitu alat kekuasaan yang bersifat hukum publik yang dapat digunakan oleh pemerintah sebagai reaksi atas ketidakpatuhan terhadap kewajiban yang terdapat dalam norma hukum administrasi.

Berdasarkan definisi ini, setidaknya ada empat unsur sanksi dalam Hukum Administrasi, yaitu alat kekuasaan (machtmiddelen), bersifat hukum publik (publiekrechtelijke), digunakan oleh pemerintah (overheid), sebagai reaksi atas ketidakpatuhan (reactive op niet-naleving). Sanksi merupakan inti dari kelancaran atau penegakan Hukum Administrasi Negara ${ }^{20}$. Sanksi akan menjamin penegakan Hukum Administrasi karena sanksi salah satu

\footnotetext{
${ }^{15}$ Ridwan, HR. (2006) Hukum Administrasi Negara, Jakarta : Rajawali Pers, hlm 298

${ }^{16}$ P. Nicolai dkk (1994), Bestuursrecht. Amsterdam. him. 469

${ }^{17}$ Hadjon, M. P, (1996)Penegakan Hukum Administrasi dalam Pengelolaan Lingkungan Hidup, Tulisan dalam , Butir-butir Gagasan tentang Penyelenggaraan Hukum dan Pemerintahan yang Layak, B. Arief Sidarta, dkk (editors). Bandung; Citra Aditya Bakti,),Hlm. 337

${ }^{18}$ Mawardi. I, (2014) Dinamika Sengketa Hukum Administrasi di Pemilukada, (Yogyakarta : Rangkang, 2014) hlm 136

${ }^{19}$ H.D. van Wijk/Konijnenbelt, (1995) Hoofdstukken van Administratief Recht. Vuga, s'Gravenhage, 1995. him. 327

${ }^{20}$ J.B.J.M. ten Berge, Beschermin Tegen Overheid, W.E.J Tjeenk Willink, Zwole, (1995) hlm 94
} 
intsrumen untuk memaksakan tingkah laku para warga negara pada umumnya dan khususnya instansi pemerintah. Oleh sebab itulah sanksi sering merupakan bagian yang melekat pada nama hukum tertentu. Sanksi Administrasi adalah :

" Administrate/sancties zijn dus sancties, die voortspruiten iut de relatie overheid-onderdaan en die zonder tussenkomst van derden en met name zonder rechterlijke machtiging rechtstreeks door de administrate zelf kunnen worden opgelegd"

Artinya: sanksi administrasi adalah sanksi yang muncul dari hubungan atara pemerintah dan warga negara dan yang dilaksanakan tanpa perantaram pihak ketiga, yaitu tanpa perantara kekuasaan peradilan, tetapi dapat secara langsung dilaksanakan oleh sendiri. ${ }^{21}$

Konteks penegakan hukum administrasi pemilu dikaitkan dengan teori penegakan sanksi hukum administrasi yang telah diurai diatas maka dapat dianalisis bahwa (1) penegakan hukum administrasi pemilu akan tegak jika ditopang oleh ancaman sanksi yang tegas dan jelas. (2) Sanksi administrasi pemilu merupakan implementasi atau bagian dari pertanggungjawaban hukum bagi penyelenggra pemilu yang tidak melaksanakan tugasnya sesuai peraturan perundang-uundangan kepemiluan. (3) Penerapan sanksi merupakan langkah represif untuk memaksakan kepatuhan (4) Sifat sanksi administrasi adalah reparatoir-comdemnatoir yaitu pemulihan kembali pada keadaan semula dan memberikan hukuman.

Teori diatas dihubungkan dengan fakta yang ada bahwa banyak terjadi pelanggaran hukum administrasi pemilu yang berakibat fatal dan menghilangkan hak demokrasi seseorang maka sudah selayaknya Pasal 461 ayat (6) Undang - undang 7 Tahun 2017 untuk direvisi sebagai upaya Penegakan Hukum Administrasi Pemilu. Penegakan hukum (law enforcement) dalam arti luas bukan hanya mencakup kegiatan untuk melaksanakan dan menerapkan regulasi ketentuan perundang-undangan yang menjadi dasarnya penyelenggraan pemilu, melainkan mencakup tindakan hukum terhadap setiap pelanggaran atau penyimpangan hukum yang dilakukan subjek hukum..$^{22}$

Ada tiga suku kata yang terkandung dalam teori efektivitas hukum, yaitu teori, efektivitas, dan hukum. Terdapat dua istilah yang berkaitan dengan efektivitas, yaitu efektif dan keefektifan. Efektif artinya (1) ada efeknya (akibatnya, pengaruhnya, kesannya), (2) manjur atau mujarab, (3) dapat membawa hasil, berhasil guna (tentang usaha, tindakan), (4) mulai berlaku (tentang undang-undang, peraturan). Keefektifan artinya (1) keadaan berpengaruh, hal berkesan, (2) kemanjuran; kemujaraban, (3) keberhasilan (usaha, tindakan), dan (4) hal mulai berlakunya (undangundang, peraturan). ${ }^{23}$ Efektivitas hukum adalah "Apakah orang-orang pada kenyataannya berbuat menurut suatu cara untuk menghindari sanksi yang

\footnotetext{
${ }^{21}$ RidwanHR.Op.Cit.hlm.289

${ }^{22}$ Wiyanto, R, (2014) Penegakan Hukum Pemilu, DPR, DPD, dan DPRD, Bandung: Mandar Maju 2014 hlm 40

${ }^{23}$ Salim, Nurbani. E. S (2013), Penerapan Teori Hukum pada Penelitian Tesis dan Disertasi, Jakarta : Raja Grafindo Persada, hlm 302
} 
diancamkan oleh norma hukum atau bukan, dan apakah sanksi tersebut benar-benar dilaksanakan bila syaratnya terpenuhi atau tidak terpenuhi." 24 "Hukum akan menjadi efektif jika tujuan keberadaan dan penerapannya dapat mencegah perbuatan-perbuatan yang tidak diinginkan dapat menghilangkan kekacauan. Hukum yang efektif secara umum dapat membuat apa yang dirancang dapat diwujudkan. Jika suatu kegagalan, maka kemungkinan terjadi pembetulan secara gampang jika terjadi keharusan untuk melaksanakan atau menerapkan hukum dalam suasana baru yang berbeda, hukum akan sanggup menyelesaikannya." 25

Faktor-faktor yang memengaruhi kegagalan di dalam pelaksanaan hukum adalah salah satunya karena norma hukum yang kabur atau tidak jelas dan penyelenggra yang tidak memiliki integritas. Sistem hukum meliputi substansi, struktur, dan budaya hukum, berikut uraian masing-masing elemen, 3 yaitu pertama, Substansi hukum adalah aturan, norma dan pola tingkah laku manusia yang berada dalam sistem itu. Pengertian substansi tidak hanya terbatas pada hukum tertulis, tetapi juga hukum yang hidup dan berlaku dalam masyarakat; kedua, struktur hukum adalah yang merupakan institusional kedalam lintas hukum seperti pengadilan tingkat pertama, banding dan kasasi, serta integrated criminal justice system; ketiga, budaya hukum adalah sikap-sikap dan nilai-nilai yang berhubungan dengan hukum, yang terkait dengan tingkah laku yang berhubungan hukum dengan lembaganya, baik positif maupun negatif. ${ }^{26}$

Merujuk pada substansi tentunya penerapan hukum administrasi pemilu bagi penyelenggra pemilu tentunya tidak akan efektif karena dalam rumusan pasal 461 ayat 6 Undang - undang 7 Tahun 2017 hanya menyebutkan sanksi teguran tertulis padahal jika kita telisik lebih jauh pelanggaran administrasi pada pemungutan dan penghitungan suara yang dilakukan oleh penyelenggra pemilu bervariasi ada yang ringan tanpa menimbulkan dampak, namun ada pula yang berakibat fatal sehingga berdampak hilangnya hak suara dari pemilih dan dapat berakibat pemungutan/penghitungan suara ulang. Tentunya penegakan sanksi administrasi pemilu bagi penyelenggra pemilu tidak akan efektif karena substansi hukumnya lemah. Idealnya sanksi yang diancamkan dalam undangundang itu haruslah berpadanan dengan sifat undang-undang yang dilanggar.

Dalam kerangka Pemilu berdasarkan ketentuan Pasal 55 ayat (1) Perbawaslu 8 Tahun 2018 bahwa dalam hal putusan Bawaslu/Bawaslu Provinsi/Bawaslu Kabupaten/Kota menyatakan laporan Pelanggaran Administratif Pemilu terbukti, amar putusan berbunyi, "Memutuskan", serta: menyatakan terlapor, terbukti secara sah dan meyakinkan melakukan Pelanggaran Administratif Pemilu; memerintahkan kepada KPU, KPU Provinsi, tau KPU Kabupaten/Kota untuk melakukan perbaikan administrasi terhadap tata cara, prosedur, atau mekanisme pada tahapan Pemilu sesuai

\footnotetext{
${ }^{24}$ Kelsen, H, (2006) Teori Umum tentang Hukum dan Negara, Bandung: Nusa Media, him. 39.

${ }^{25}$ Liwupung, F.T, "Eksistensi dan Efektivitas Fungsi Du'a Mo'ang (Lembaga Peradilan Adat) dalam

Penyelesaian Sengketa Adat Bersama Hakim Perdamaian Desa di Sikkan Flores NTT", tanpa tahun, hlm. 80.

${ }^{26}$ Suharso Agung Basuki (2010), Tindak Pidana Pemilu Legislatif Di Kabupaten Banyumas Dan Purbalingga (Studi Tentang Kebijakan Formulasi Dan Penerapan Undang-Undang No. 10 Tahun 2008 Tentang Pemilihan Umum), Jurnal Dinamika Hukum Vol. 10 No. 2 Mei 2010, hlm 143
} 
dengan ketentuan peraturan perundang-undangan; memberikan teguran tertulis kepada terlapor; memerintahkan kepada KPU, KPU Provinsi, atau KPU Kabupaten/Kota agar terlapor untuk tidak diikutkan pada tahapan Pemilu dalam penyelenggaraan Pemilu; dan/atau memberikan sanksi administratif lainnya kepada terlapor sesuai dengan ketentuan undangundang mengenai Pemilu. Berdasarkan paparan di atas, meskipun dalam kerangka Pemilu bunyi amar putusan penanganan administrasi pemilu berbentuk rigid dan kaku yang kecil membuka peluang Majelis memberikan putusan seadil-adilnya berdasarkan nilai-nilai yang hidup (ex aequo et bono). ${ }^{27}$

Untuk mewujudkan penyelenggaraan Pemilukada yang berkualitas dan memiliki integritas tinggi maka perlu dilakukan penyempurnaan terhadap aturan yang telah ada melalui penambahan aturan, penegasan maksud dan sinkronisasi antar peraturan perundang-undangan yang telah ada salah satu diantaranya melalui pembuatan instrumen-instrumen komplain atas terjadinya pelanggaran pemilu yang lengkap, mudah diakses, terbuka, dan adil. Lebih penting lagi memastikan bahwa aturan main yang ditetapkan tersebut dijalankan secara konsisten oleh semua pihak baik penyelenggara, peserta dan masyarakat. ${ }^{28}$ Tersedianya aturan yang konkrit dan implementatif penting untuk menjamin kepastian dan keadilan hukum sehingga pemilu memiliki landasan legalitas dan legitimasi yang kuat sehingga pemerintahan yang dihasilkan melalui pemilu tetap mendapatkan dukungan masyarakat luas. Untuk itu, maka segala pelanggaran yang terjadi dalam proses pelaksanaan pemilu harus diselesaikan secara adil, terbuka dan konsisten. ${ }^{29}$

Pemilihan umum secara langsung oleh rakyat merupakan sarana perwujudan kedaulatan rakyat guna menghasilkan pemerintahan negara yang demokratis berdasarkan Pancasila dan Undang-Undang Dasar Negara Republik Indonesia Tahun 1945. Pasal 1 ayat (2) UUD 1945 menyatakan bahwa "kedaulatan berada di tangan rakyat dan dilaksanakan menurut Undang-Undang Dasar". Penyelenggaraan pemilihan umum secara langsung, umum, bebas, rahasia, jujur dan adil dapat terwujud apabila dilaksanakan oleh penyelenggara pemilihan umum yang mempunyai integritas, profesionalisme dan akuntabilitas. ${ }^{30}$

Untuk sanksi administrasi dalam Undang - undang 7 Tahun 2017 belum memenuhi asas-asas kejelasan tujuan yaitu bahwa setiap pembentukan peraturan perundang-undangan harus mempunyai tujuan yang jelas yang hendak dicapai dan asas dapat dilaksanakan yang mengisyaratkan setiap pembentukan peraturan perundang-undangan harus memperhitungkan efektivitas peraturan perundang-undangan tersebut di dalam masyarakat, baik secara filosofis, sosiologis, maupun yuridis.

\footnotetext{
${ }^{27}$ Nasir, I.(2020), Analisis Hukum Pelanggaran Administrasi Pemilu/Pemilihan, Khazanah Hukum, Vol. 2 No. 1: 41-50, hlm 48

${ }^{28}$ Patawari, P. (2019). Standar Hukum Internasional Penyelenggara Pemilihan Umum, Dan Pengaruhnya Terhadap Hukum Negara Indonesia. Pleno Jure, 8(1), 25-38. hlm, 28

${ }^{29}$ Andrizal (2017), Penyelesaian Hukum Pelanggaran Pemilu Dalam Pemilihan Kepala Daerah Kota Pekanbaru Berdasarkan Undang-Undang Nomor 10 Tahun 2016, Jurnal Hukum Respublica, Vol. 17 No. 1 Tahun 2017, hlm 167

${ }^{30}$ Mulyadi, D (2019), Analisis Penerapan Bentuk-Bentuk Tindak Pidana Pemilu, Jurnal Ilmiah Galuh Justisi, Vol. 7 No. 1- Maret 2019, hlm 14-15
} 
Pemilu/Pemilihan sejatinya dijalankan sesuai dengan peraturan perundang-undangan atau dilaksanakan berdasarkan tata cara, prosedur atau mekanisme yang diatur ${ }^{31}$. Apabila dijalankan tidak sesuai dengan peraturan perundang- undangan maka yang terjadi adalah ketidak percayaan (distrust public) ${ }^{32}$ terhadap hasil pemilu/pemilihan dan dapat dikatakan bahwa demokrasi substansi telah gagal. Untuk mencegah hal tersebut maka penegakan hukum administrasi yaitu kesesuaian tata cara, prosedur atau mekanisme harus benar-benar dijaga; termasuk terhadap pelanggarannya harus dilakukan penanganan dengan penuh berintegritas, akuntabel, dan berkualitas $^{33}$

Efektifitas Undang-Undang Pemilu dengan berbagai macam persoalan yang terjadi pada tahun 2019 itu sudah selayaknya menjadi bahan evaluasi kita bersama agar kedepan lahir sebuah undang-undang pemilu yang lebih baik. Perubahan dalam pelaksanaan pemilu memang hal yang wajar, hukum pemilu dan pilkada selalu berkembang seiring dengan kebutuhan dalam masyarakat. Berkaitan dengan masih terdapatnya kelemahan dalam Undang-undang Nomor 7 Tahun 2017 perlu dilakukan pemetaan berikutnya terhadap Rancangan Undang-Undang (RUU) Pemilu yang baru.

\section{SIMPULAN}

Penerapan Sanksi Administratif Pemilu bagi Penyelenggara Pemilu dirasakan belum efektif karena sanksi yang dapat dijatuhkan bagi penyelanggara pemilu yang terbukti melakukan pelanggraan administratif pemilu di Kota Palopo hanya berupa teguran tertulis sesuai pasal 461 ayat 6 Undang-Undang 7 Tahun 2017. Tentunya tidak menimbulkan efek jera dan sanksi tersebut tidak berfungsi sebagai pencegahan agar penyelengara pemilu bekerja sesuai norma/aturan yang berlaku.

\section{SARAN}

Diperlukan revisi Undang-Undang 7 Tahun 2017 tentang Pemilihan umum khusus mengenai sanksi administrasi terhadap pelanggran administrative yang dilakukan oleh penyelenggara pemilu. Sanksi yang diberikan seharusnya dapat lebih jelas dan tegas sehingga sanksi yang dijatuhkan tersebut sepadan dengan jenis pelanggraan yang dilakukan yang pada akhirnya sanksi tersebut dapat berfungsi sebagai pencegahan agar penyelengara pemilu bekerja sesuai norma/aturan yang berlaku dan efekjera.

\section{DAFTAR RUJUKAN}

Andrizal (2017), Penyelesaian Hukum Pelanggaran Pemilu Dalam Pemilihan Kepala Daerah Kota Pekanbaru Berdasarkan Undang-Undang Nomor

\footnotetext{
${ }^{31}$ Hidayat, A. (2020), Manfaat Pelaksanaan Pemilu Untuk Kesejahtraan Masyarakat. Madani Legal Review, 2 (1) hal 61

${ }^{32}$ Sukriono, D. (2009). Menggagas sistem pemilihan umum di Indonesia. Konstitusi Jurnal, 2(1), 8.

${ }^{33} \mathrm{Ja}$ Jar, M. (2018), Eksistensi dan Integritas Bawaslu dalam Penanganan Sengketa Pemilu. Madani Legal Review, 2(1) hal 59
} 
10 Tahun 2016, Jurnal Hukum Respublica, Vol. 17 No. 1 Tahun 2017, hlm 151-169.

DOI : https://doi.org/10.31849/respublica.v17i1.1454

Basuki, S. A. (2010), Tindak Pidana Pemilu Legislatif Di Kabupaten Banyumas Dan Purbalingga (Studi Tentang Kebijakan Formulasi Dan Penerapan Undang-Undang No. 10 Tahun 2008 Tentang Pemilihan Umum), Jurnal Dinamika Hukum Vol. 10 No. 2 Mei 2010, hlm 129-146 DOI : http://dx.doi.org/10.20884/1.jdh.2010.10.2.146

Damanik. F. F, Kalo. S, Putera. E, Nasution, M (2018) , Perbuatan Mengaku Dirinya Sebagai Orang Lain Dalam Pemungutan Suara Pada Pemilihan Umum Legislatif (Studi Kasus: Putusan Nomor:01/Pid.S/2014/P.N.Mdn Dan Putusan Nomor:02/Pid.B/2014/P.N.Mdn), USU Law Journal, Vol.6. No.4 (Juli 2018), hlm 52 - 60

DOI : http://repositori.usu.ac.id/handle/123456789/3881

Fahmi, K. (2015), Sistem Penanganan Tindak Pidana Pemilu, System for The Crime of Election, Jurnal Konstitusi, Vol. 12, Nomor 2, Juni 2015, Hlm $264-283$

DOI: https://doi.org/10.31078/jk1224

Friedman, M. L, (2013) Sistem Hukum Perspektif Ilmu Sosial terjemahan dari Buku Lawrance M. Friedman, The Legal System : Social Science Perspektif Bandung : Nusa Media.

H.D. van Wijk/Konijnenbelt, (1995) Hoofdstukken van Administratief Recht. Vuga, s'Gravenhage, 1995.

Hadjon, M. P, (1996)Penegakan Hukum Administrasi dalam Pengelolaan Lingkungan Hidup, Tulisan dalam, Butir-butir Gagasan tentang Penyelenggaraan Hukum dan Pemerintahan yang Layak, B. Arief Sidarta, dkk (editors). Bandung; Citra Aditya Bakti,).

Hantoro. M. N. (2014), Pelanggaran Administrasi Pemilu Dan Sengketa Tata Usaha Negara Pemilu Anggota Dpr, Dpd, Dan Dprd Tahun 2014, Violation Of Administration And Administrative Dispute At The Election Of Members Of Dpr, Dpd, And Dprd In 2014, Jurnal Negara Hukum : membangun hukum untuk keadilan dan kesejahteraan, Vol. 5 No.2 Tahun 2016, hlm 107 - 125

DOI: https://doi.org/10.22212/jnh.v5i2.236

Hidayat, A. (2020). Manfaat Pelaksanaan Pemilu Untuk Kesejahteraan Masyarakat. Politicon: Jurnal Ilmu Politik, 2(1), 61-74.

DOI:https://www.researchgate.net/publication/340313569 Manfaa t Pelaksanaan Pemilu Untuk Kesejahteraan Masyarakat

Ja'far, M. (2018). Eksistensi Dan Integritas Bawaslu Dalam Penanganan Sengketa Pemilu. Madani Legal Review, 2(1), 59-70. 
DOI: https://doi.org/10.31850/malrev.v2i1.332

J.B.J.M. ten Berge, (1995). Beschermin Tegen Overheid, W.E.J Tjeenk Willink, Zwole.

Kelsen, H, (2006) Teori Umum tentang Hukum dan Negara, Bandung: Nusa Media.

(2014) Teori Umum tentang Hukum dan Negara Terjemahan dari

General Theory of Law and State Bandung : Nusa Media.

Liwupung, F.T, "Eksistensi dan Efektivitas Fungsi Du'a Mo'ang (Lembaga Peradilan Adat) dalam Penyelesaian Sengketa Adat Bersama Hakim Perdamaian Desa di Sikkan Flores NTT".

Mawardi. I, (2014) Dinamika Sengketa Hukum Administrasi di Pemilukada, Yogyakarta : Rangkang, 2014.

Mulyadi, D (2019), Analisis Penerapan Bentuk-Bentuk Tindak Pidana Pemilu, Jurnal Ilmiah Galuh Justisi, Vol. 7 No. 1- Maret 2019 , hlm 14-28 DOI: http://dx.doi.org/10.25157/jigj.v7i1.2144

Nasir, I (2020), Analisis Hukum Pelanggaran Administrasi Pemilu/Pemilihan, Khazanah Hukum, Vol. 2 No. 1: 41-50, hlm $41-50$ DOI: $10.15575 /$ kh.v2i1.7689

Nawi, S. (2013) Penelitian Hukum Normatif Versus Penelitian Hukum Empiris, Jakarta : Raja Grafindo Persada,

P. Nicolai dkk (1994), Bestuursrecht. Amsterdam.

Patawari, P. (2019). Standar Hukum Internasional Penyelenggara Pemilihan Umum, Dan Pengaruhnya Terhadap Hukum Negara Indonesia. Pleno Jure, 8(1), 25-38

Ridwan, HR. (2006) Hukum Administrasi Negara, Jakarta : Rajawali Pers.

Riza, F., Mohammad \& Ruhermansyah, Perihal Penegakan Hukum Pemilu (Jakarta : Bawaslu 2019)

Salim, Nurbani. E. S (2013), Penerapan Teori Hukum pada Penelitian Tesis dan Disertasi, Jakarta : Raja Grafindo Persada.

Sekarwidhi, N..(2015). Penyelesaian Pelanggaran Pemilu Tahun 2014 Dan Pemilu Kepala Daerah Dan Wakil Kepala Daerah Tahun 2015 Di Jawa Tengah, Completion Of 2014 Election Violation And Regional Election And Regional Head Of Region In 2015 In Central Java .Science Government Fisip Undip, Semarang, Journal of Politic and Government Studies, vol. 7, no. 3, pp. 211-220, Jul. 2018. DOI : http://garuda.ristekbrin.go.id/documents/detail/1584830 
Pleno Jure, Vol 9 (2), Asbudi, Penerapan Sanksi Pelanggaran ...

Wiyanto, R, (2014) Penegakan Hukum Pemilu, DPR, DPD, dan DPRD, Bandung: Mandar Maju 2014. 